\title{
Comparative Study on the Technical Complexity of China and India Service Export and Its Impact Factors
}

\author{
Wan Lu, Yizhong Fu* \\ School of Economics and Management \\ Beijing Forestry University \\ Beijing, China \\ wanlu@bjfu.edu.cn, fuyizhong@bjfu.edu.cn*
}

\begin{abstract}
Service sectors are exhibiting increasing importance in domestic economy and service trade attracted more attentions. China and India, as the top emerging economies, are similar in many dimensions, such as population base, social environment, economic policies, and national development strategies. Therefore, their trade in services are comparable. In this paper we used the global service trade data to calculate and compare the technical complexity of service exports between China and India to get some insights for fixing China's problem of export structure and long-term deficit. We selected the data of 34 countries/regions as sample which represented more than $84 \%$ of the world's total trade in services from 2005 to 2016, and calculated the technical complexity of China and India's service exports. We established a regression model to discuss the impact factors. The results indicated that the complexity of India's service export technology surpassed China in 2005-2015, and in 2016, China overcame India. The level of economic development and higher education level had a significant positive impact on the complexity of China's service export technology. While the impact of FDI, quality of governance was not significant, the impact of service trade openness and the effect of $R \& D$ investment was uncertain.
\end{abstract}

Keywords-China; India; Service trde; Export technical complexity; Impact factors

\section{INTRODUCTION}

Economic globalization changed the world tremendously. Developed countries have shifted from manufacturing to service economy, and service trade turns out to be a new boost to global economic growth. From 1981 to 2017 , international service trade grew at an average annual rate of $7.4 \%$. The development of service trade has become an important indicator to measure the trade competitiveness of a country or region. The importance of trade in services in China's economy has gradually increased. Since 2012, the Chinese government has successively issued the "Service Industry Development Plan" and "China International Service Outsourcing Industry Development Plan", which have promoted the formation of China's service trade development planning system. Even if China's service trade is developing rapidly, there are still problems in the service trade structure, such as at the low end of the value chain and of high market concentration [1].

India, being an emerging economy as well, has not been

This research was sponsored by the Central University Fundamental Science and Research findings of Beijing Forestry University (Project No.: 2017ZY58; 2017ZY57), and the National Social Science Foundation of China (Project No.: 17BJY018). underdeveloped since the implementation of economic reforms in the 1990s. Since 1997, India's service import and export has grown at an annual growth rate of more than $10 \%$, and it had not slowed down until 2012. Since 2008, India's service trade has maintained a surplus and even a trend of gradual expansion. By 2014, India had entered the top 10 of the global trade in services, ranking 8th. In 2015, India's service trade hit a new record of $\$ 32.7$ billion.

In 2017, China and India's GDP growth rate was $6.8 \%$ and $6.5 \%$ respectively and service trade was also developing rapidly. In addition, China and India are similar in many aspects such as population base, social environment, economic policy, national development pattern and strategies [2]. These similarities of the two countries made the comparative study between China and India more rational and reasonable.

With the development of service trade, technical factors have received more and more attention, hence the technical differences of services determine both the country's comparative advantages and trade patterns (D.F. Burgess, 1990) [3]. Therefore, this paper compared and analyzed the export technical complexity of China and India's service trade, and explored the factors affecting the complexity of export technology in China and India, and further identified China's deficiency of trade in services. Consequently, we proposed some suggestions and policies for better development of China's trade in services.

\section{DEFINITION OF SERVICE TRADE AND RELATED THEORIES}

\section{A. Definition of Trade in Services}

Countries and the scholars have not reached a consensus over the definition of trade in services. So far, there is no unified and authoritative interpretation of the concept of trade in services. Therefore, researchers always summarized some authoritative descriptions according to national statistical reports and trade literature [4]. In addition, Article 1.3 of the GATS stated that "services" include all services in all sectors, except for administrative services provided by government, which were neither provided on a commercial basis nor by one or more competitive providers. In this article, we classified trade in services according to the fifth edition of the balance of payments and international investment position issued by the 
IMF. Trade services included Transportation Services, Travel Services and Other Services, while Other Services included Communication Services, Insurance Services, Construction Services, Financial Services, Computer and Information Services, Other Business Services, Royalties and license Services, Personal, Cultural and Recreation Services, and Government Services. However, due to the noncompetitiveness of government services, government services were excluded from the research.

\section{B. Related Theory}

1) International service trade applicability theory: The "applicability theory" of international service trade considered that service trade and commodity trade were the same, and the comparative advantage theory of commodity trade can explain the occurrence of trade in services. In order to prove the theory of applicability, some scholars had carried out a series of empirical analysis by comparing the resource endowments and technical differences of freight, passenger transport and other non-governmental services, and found that the theory were also applicable to trade in services. Therefore, when scholars used the technical complexity to measure the level of export technology and studied its impact factors to achieve indirect research on the factors affecting the development of trade in goods, the same thing can be done for trade in services. This paper was also based on the above theory.

2) Export technology complexity promotes economic growth: There were many studies focused on the complexity of service export technology promoting the economic growth. Among them, Yun-su Du [5] (2014) adopted Hausmann's method to measure the development and changes of China's service export technical complexity from 2000 to 2010, and then constructed an economic growth model to analyze the impact of export technical complexity. The result was that the technical complexity had a significant positive effect on China's economic growth, and there was a mutually reinforcing effect between economic growth and the complexity of export technology. Wei-hong Cai et al. (2016) [6] conducted empirical analysis on the influence of upgrade of service export technical complexity on economic growth with cross-national panel data. The research results showed that the technical complexity of service trade export had a significant impact on economic growth for all countries, while the effect on economic growth in developing countries was greater than that in developed countries. In general, the increase in the complexity of export technology can promote economic growth. In this paper, by studying the factors affecting the complexity of service export technology, we can indirectly examine the factors that promote economic growth, and then put forward corresponding suggestions on the development of service trade
III. DEVELOPMENT AND CHARACTERISTICS OF CHINA AND INDIA SERVICE EXPORTS

\section{A. Development of China's Service Export and Its Characteristics}

Since 2003, China has been the world's largest developing exporter of trade in services, and its ranking in the world increased from 8th in 2005 to 2 nd in 2014. In terms of services import, China's ranking rose from 8th in 2005 to 2 nd in the world in 2014, being top one in developing countries. By 2017, the import and export volume of China's service trade was second only to United States and ranking second in the world. In terms of proportion, the global share of China's trade in services rose from $2.2 \%$ in 2000 to $6.85 \%$ in 2016 . Specifically, the global share of service exports rose from $2 \%$ in 2000 to $4.3 \%$ in 2016; the global share of service import rose from $2.4 \%$ in 2000 to $9.4 \%$ in 2016 . Some characteristics could be observed in recent decade.

1) The scale of China's service trade was expanding: As Fig. 1 indicated, during 1995-2001, the growth rate of the total trade in service fluctuated slightly. Since China's WTO accession in 2001, the growth rate of service trade has increased significantly. After 2008, the growth rate of service import sustained to be greater than that of service exports, and increasing year by year. Affected by the economic crisis in 2009, China's total trade in services showed a downward trend. However, the service trade in the following years began to rise steadily. The scale of China's service trade was constantly expanding. According to the trend in the picture, it can be said it will continue to expand in the future.

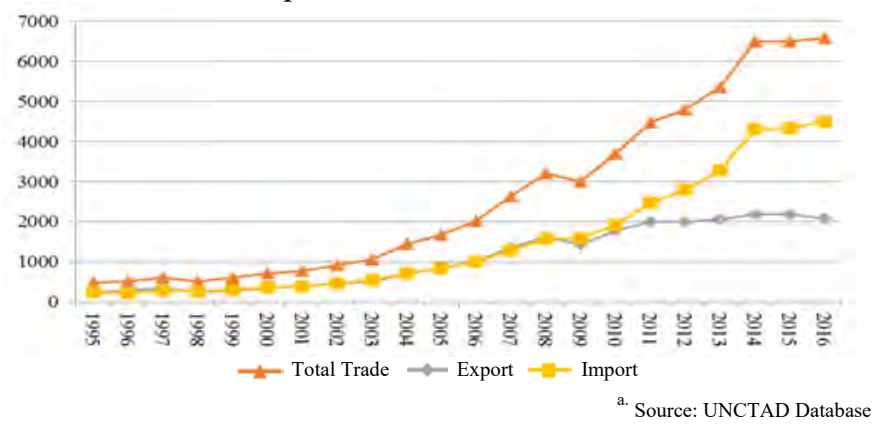

Fig. 1. China's services imports and exports from 1995 to 2016.

2) The structure of trade was unreasonable, but it was constantly optimized: China's trade volume of transportation service has grown steadily from 2005 to 2014 and has declined from 2015 to 2016. The trade volume of tourism service has been growing. The development of China's service trade was mainly based on transportation and tourism services. The sum of the two sectors trade volume accounted for more than $50 \%$ of the total in the past decade. During the period of 2005-2009, due to the deepening of trade liberalization, the growing pace of trade in emerging service has gradually accelerated and China has already obtained strong international influence or its own characteristics in some emerging high value-added service industries. Although China's service trade was dominated by transportation and 
tourism services, it was constantly optimized. As shown in Fig. 2 , the trade volume of knowledge and technology-intensive services has increased significantly in recent years; the trade in computer and information services has been growing all the way, and the development trend was good.

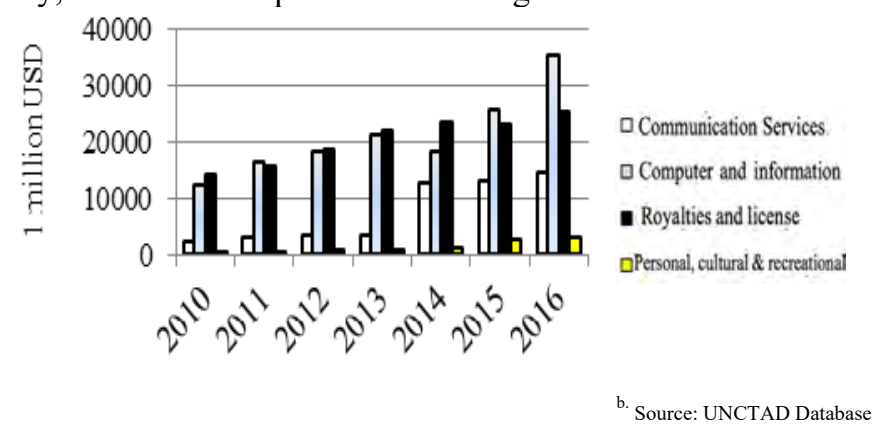

Fig. 2. Statistics of trade in selected service sectors in China.

3) Service trade deficit continues to expand: Fig. 3 indicated that China's service trade deficit sustained since 1995. Only during the period of 1996-1997 and 2005-2008, there was once a surplus. Since 2009, the trade deficit of China's service has gradually increased, reaching US\$240.9 billion in 2016, which was nearly 268 times that of 1995 . Sticking to existing trends, the trade deficit in services will continue to expand in the future.

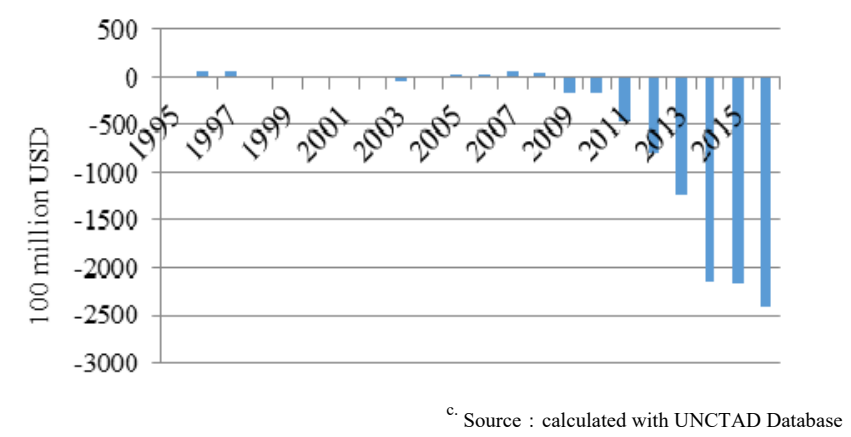

Fig. 3. China's service trade deficit from 2005 to 2016.

\section{B. Development and Characteristics of India's Service Exports}

Since the economic reforms of the 1990s, India's service trade has developed rapidly. In 2000, India's service exports ranked 25 th in the world and imports ranked 19th. Since then, except for 2009, India's service exports and imports have basically maintained an upward trend. Since 2010, India's volume of service exports and imports both entered the top ten in the world. In 2012, India ranked 7th in the world in service trade exports, second only to China and Japan in Asia, and became the second developing countries in Top 10 largest exporters [7]. In 1995, India's volume of service export was only US $\$ 6.775$ billion. By 2005, exports of services had reached US \$52.18 billion, an increase of about nine times in ten years. From 2006 to 2010, the average growth rate of service exports was $18.77 \%$. Since 2011 , the growth rate of India's service trade exports has slowed down, even in 2015 a negative growth occurred. In terms of service imports, from
2000 to 2008 , the average growth rate was $23.16 \%$, which was slower than the growth rate of service exports, resulting in a surplus in service trade. India's service trade keeps possessing a fast growth rate, a large scale, and a large surplus. There is a lot of room for the development of its service trade.

1) The total volume of service trade keeps increasing: According to India's data on import and export of services from 1995 to 2016, Fig. 4 showed that the scale of service trade has been rising. In 1995, India's import and export volume of service was US\$17.04 billion, and by 2016 it was US\$295.55 billion, 17 times that of 1995 . Exports of trade in services have grown at a rate of more than $20 \%$ since 2003 , and exports declined in 2009 due to the impact of economic crisis in 2008. Subsequently, in 2010, the export volume of service trade began to rise again, reaching US\$117.07 billion. After 2012, the growth rate of service exports declined. However, the overall import of service trade still shows an upward trend, and the scale of service trade will continue to increase in the future.

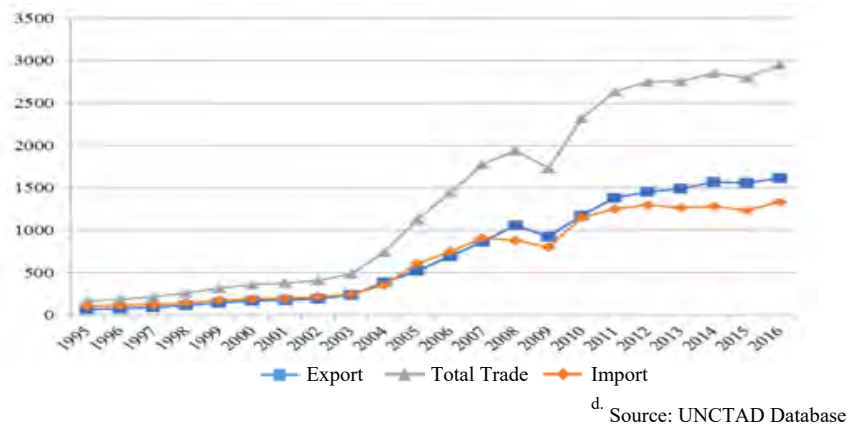

Fig. 4. India's service trade from 1995 to 2016.

2) The proportion of traditional service trade was small, and service outsourcing had become a new form of service export: The transportation services and tourism services were shown in Fig. 5 below. As the largest two traditional Indian service sectors, transportation services had always been greater than tourism services, and the proportion of tourism services and transportation services in the past ten years had not exceeded $45 \%$. In 2016, the proportion of both sectors had been reduced to less than $38 \%$. In a sense we may tell the emerging service sector was developing in India. In recent years, due to the development of information technology and the strategic adjustment of multinational corporations, service outsourcing composed of information technology outsourcing (ITO) and business process outsourcing (BPO) was gradually becoming an important part of export trade in services. And now the main service outsourcing business was rooted in developing countries. Asia is the region that obtained the largest outsourcing business. India has become an outsourcing center in Asia due to its advantages in the software outsourcing industry. At the same time, the scale of service outsourcing in the world is also expanding. 


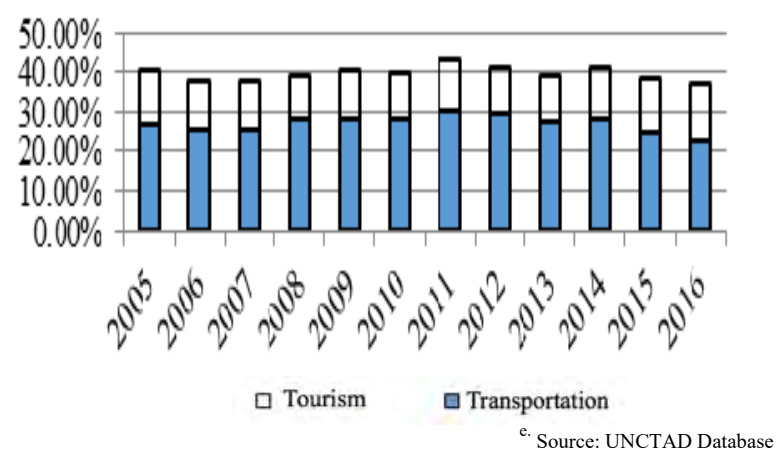

Fig. 5. Proportion of India's traditional service trade.

\section{CAlCUlation AND COMPARATIVE ANALYSIS OF THE TECHNICAL COMPLEXITY OF CHINA AND INDIA EXPORT IN SERVICES}

\section{A. Concept and Index Construction of Export Technical Complexity}

Early scholars proposed the Trade Specialization Index (TSI), which weighted the total export value of a certain product in each country to the total export value of the product in the world, and then weighted the per capita income of each country. Under the guidance of logic within this index, scholars further revised this indicator. Among them, Hanusmann's amendment to this index had been widely applied. Based on the theory of comparative advantage, he put forward the concept of export technical complexity. He believed that the higher the export technical complexity of an economy or industry, the more technical content was contained in its export products. And the overall export productivity level would be higher. There were also other scholars who defined the complexity of export technology. Although there were certain differences, in general, the export technical complexity can reflect the export technology level of a certain product in a certain country [8].

In this paper, the export technical complexity was drawn on Hausmann's calculation method, and we calculated the export technical complexity of the country's product level and country level respectively. The specific calculation methods were as follows:

The calculation of the export technical at the product level was in (1).

$$
P R O D Y_{k}=\sum_{f} \frac{x_{j k} / x_{j}}{\sum_{j}\left(x_{j k} / x_{j}\right)} Y_{f}
$$

This formula was used to calculate the export technical complexity of the global trade in services of different categories. PRODYk referred to the export technical complexity of trade in service sector $\mathrm{k}$ in global service trade, and $x j k$ referred to export value of sector $k$ of country/region $j$. $\mathrm{Xj}$ referred to the total export value of service trade of country/region $\mathrm{j}$, Yj was the per capita GDP of country/region $\mathrm{j}$, and $\mathrm{xjkXj}$ was the proportion of export of service sector $\mathrm{k}$ in total trade in services of country/region $\mathrm{j}$.

Second, the calculation of the export technical complexity at the national level was as follows:

$$
E X P Y_{j}=\sum_{k} \frac{X_{j k}}{X_{j}} P R O D Y_{\mathrm{k}}
$$

In (2), $E X P Y_{j}$ was the technical complexity of service export in country/region $j$, and the rest of the notations were explained in the same way as the product level in (1).

\section{B. Calculation of China and India's Technical Complexity Index of Service Export}

Due to the accessibility of national data and the objective reality of the extremely uneven distribution of world service trade, we examined the top 40 countries/regions in terms of total volume of service trade in 2014. Since the service trade data of six countries/regions such as Saudi Arabia, Macao, Mexico, Qatar, Czech Republic and Finland were seriously missing, they were excluded. Therefore, we selected 34 representative countries/regions as samples whose sum of service trade accounted for more than $84 \%$ of the world. The data of the sample countries/regions from 2005 to 2013 comes from the United Nations Development Conference (UNCTAD), and the export trade data of services from 2014 to 2016 comes from the WTO statistics database. Both data sources shared the same base library and their data were consistent and comparable.

With the export data of service trade from 2005 to 2016 in 34 countries/regions of the sample, the PRODY index of the global service trade sub-sector was calculated according to (1). As shown in Table I, it can be found that the technical complexity of financial services export was the highest for more than ten years, and the complexity of personal cultural and entertainment services export was also increasing year by year. Traditional services, including transportation and tourism services, experienced a modest increase in export technical complexity in 2000-2016.

1) China's technical complexity index of service export: By calculating the technical complexity of global service exports, we can furtherly conclude that of China's service trade. According to (2), the technical complexity of China's service export from 2000 to 2016 was finally obtained (see Table II). Since 2004, the technical complexity of service export was increased from 30,000. Since then, the technical complexity of China's service export had seen a steady increase year by year in the past decade.

2) India's technology complexity index of service export: The technical complexity of India's service export from 2000 to 2016 was as shown in Table III below. It can be seen that India, as a developing country, had complicated service export technology. In 2002, it reached 30,000 and maximized in 2015 to 37,778 . However, it fell to 32,479 in 2016 . 
TABLE I. PRODY Index of TRAde IN Global Service SeCtors FROM 2000 TO 2016

\begin{tabular}{|c|c|c|c|c|c|}
\hline Year & $\begin{array}{c}\text { Trave } \\
1\end{array}$ & $\begin{array}{c}\text { Touris } \\
\mathbf{m}\end{array}$ & $\begin{array}{c}\text { Communic } \\
\text { ation }\end{array}$ & $\begin{array}{c}\text { Constructi } \\
\text { on }\end{array}$ & $\begin{array}{c}\text { Insuran } \\
\text { ce }\end{array}$ \\
\hline 2001 & 33559 & 25947 & 30502 & 27004 & 35430 \\
\hline 2002 & 33869 & 27328 & 35388 & 26135 & 42794 \\
\hline 2003 & 33080 & 26171 & 31763 & 26622 & 44007 \\
\hline 2004 & 33891 & 27430 & 33131 & 26070 & 46330 \\
\hline 2005 & 34003 & 28037 & 33222 & 25930 & 47455 \\
\hline 2006 & 35115 & 28408 & 33632 & 26139 & 47487 \\
\hline 2007 & 35613 & 29023 & 34746 & 26869 & 48131 \\
\hline 2008 & 35535 & 28886 & 37100 & 26563 & 47435 \\
\hline 2009 & 34144 & 27821 & 36620 & 25763 & 45135 \\
\hline 2010 & 34778 & 28399 & 37260 & 26590 & 46272 \\
\hline 2011 & 35448 & 28697 & 38324 & 26352 & 44989 \\
\hline 2012 & 35499 & 28842 & 38709 & 26345 & 44732 \\
\hline 2013 & 36010 & 28796 & 39190 & 26156 & 45951 \\
\hline 2014 & 36911 & 28563 & 38534 & 27891 & 45987 \\
\hline 2015 & 37302 & 28723 & 39425 & 29732 & 46946 \\
\hline 2016 & 38112 & 30301 & 29944 & 30380 & 49778 \\
\hline year & $\begin{array}{c}\text { Finan } \\
\text { ce }\end{array}$ & IT & $\begin{array}{c}\text { Franchise } \\
\text { royalty }\end{array}$ & $\begin{array}{c}\text { Other } \\
\text { Commerci } \\
\text { al } \\
\text { service }\end{array}$ & $\begin{array}{c}\text { Entertai } \\
\text { nment } \\
*\end{array}$ \\
\hline 2000 & 41303 & 28737 & 41595 & 28443 & 27958 \\
\hline 2001 & 41856 & 27858 & 42323 & 29411 & 29780 \\
\hline 2002 & 58499 & 28178 & 43904 & 31621 & 24676 \\
\hline 2003 & 58755 & 29646 & 44094 & 31361 & 25723 \\
\hline 2004 & 59674 & 35104 & 45135 & 30833 & 26741 \\
\hline 2005 & 59746 & 35917 & 46915 & 31903 & 29718 \\
\hline 2006 & 61545 & 36371 & 48576 & 32904 & 32875 \\
\hline 2007 & 62406 & 35529 & 49675 & 34615 & 35387 \\
\hline 2008 & 61258 & 35101 & 49122 & 34919 & 35942 \\
\hline 2009 & 58079 & 33952 & 47372 & 33468 & 38686 \\
\hline 2010 & 59235 & 34805 & 48745 & 34451 & 42383 \\
\hline 2011 & 59780 & 33914 & 48735 & 35171 & 44187 \\
\hline 2012 & 59729 & 33989 & 49462 & 34870 & 44214 \\
\hline 2013 & 59264 & 34396 & 49885 & 35281 & 44456 \\
\hline 2014 & 58402 & 37919 & 50679 & 35459 & 47001 \\
\hline 2015 & 60027 & 39708 & 50837 & 36792 & 45305 \\
\hline 2016 & 60481 & 22208 & 51600 & 38371 & 43116 \\
\hline
\end{tabular}

TABLE II. TECHNICAL COMPLEXITY OF CHINA's SERVICE EXPORT FROM 2000 TO 2016

\begin{tabular}{|l|l|l|l|}
\hline year & \multicolumn{1}{|c|}{ EXPY index } & Year & EXPY index \\
\hline 2000 & 27842.88 & 2009 & 31599.76 \\
\hline 2001 & 28171.17 & 2010 & 32546.15 \\
\hline 2002 & 29678.72 & 2011 & 32996.88 \\
\hline 2003 & 29747.52 & 2012 & 33340.76 \\
\hline 2004 & 30250.19 & 2013 & 33923.43 \\
\hline 2005 & 30906.42 & 2014 & 34210.86 \\
\hline 2006 & 31825.95 & 2015 & 34634.85 \\
\hline 2007 & 33049.42 & 2016 & 36060.60 \\
\hline 2008 & 33072.68 & \multicolumn{3}{|c|}{} \\
\hline \multicolumn{4}{|c|}{${ }^{\text {h. }}$ Source : calculated with UNCTAD and WTO Database }
\end{tabular}

3) Comparative analysis of the technical complexity of China and India's service export: The above-mentioned technical complexity of service export of China and India was plotted as shown in Fig. 6 below. We could observe the fluctuations in the complexity of export technology of China and India were very similar. Besides, the technical complexity of India's exports had been higher than that of China's (except year 2016). From 2000 to 2004, for China, the growth rate of export technical complexity was stabilized while India's export technical complexity had fluctuated several times over this period with a declined complexity of export technology in 2003 and 2008 separately. India's export technical complexity increased fast since 2004. Between 2005 and 2016, it can be roughly divided into three stages: from 2005 to 2007, both the technical complexity of China and India showed an upward trend. In 2008, due to the impact of the economic crisis, it began to decline and rebounded in 2009. From 2011 to 2016, China's service export technical complexity grew at an average annual rate of $1.8 \%$, while that of India's obtained an averaged negative growth rate. In general, it was believed that the technical complexity of India's service export surpassed that of China for a long time, mainly because of India's relatively relaxed service trade development environment and its advantages in the field of computer and information services.

TABLE III. TECHNICAL COMPLEXITY OF INDIA'S SERVICE EXPORT FROM 2000 TO 2016

\begin{tabular}{|l|l|l|l|}
\hline \multicolumn{1}{|c|}{ year } & \multicolumn{1}{|c|}{ EXPY index } & \multicolumn{1}{|c|}{ Year } & $\begin{array}{c}\text { EXPY } \\
\text { index }\end{array}$ \\
\hline 2000 & 29208.26 & 2009 & 34262.42 \\
\hline 2001 & 29043.63 & 2010 & 35355.04 \\
\hline 2002 & 31003.43 & 2011 & 35302.17 \\
\hline 2003 & 30362.72 & 2012 & 35020.41 \\
\hline 2004 & 32617.90 & 2013 & 35480.16 \\
\hline 2005 & 33760.89 & 2014 & 36719.95 \\
\hline 2006 & 34833.95 & 2015 & 37777.85 \\
\hline 2007 & 35604.48 & 2016 & 32478.91 \\
\hline 2008 & 35631.16 & & \\
\hline
\end{tabular}

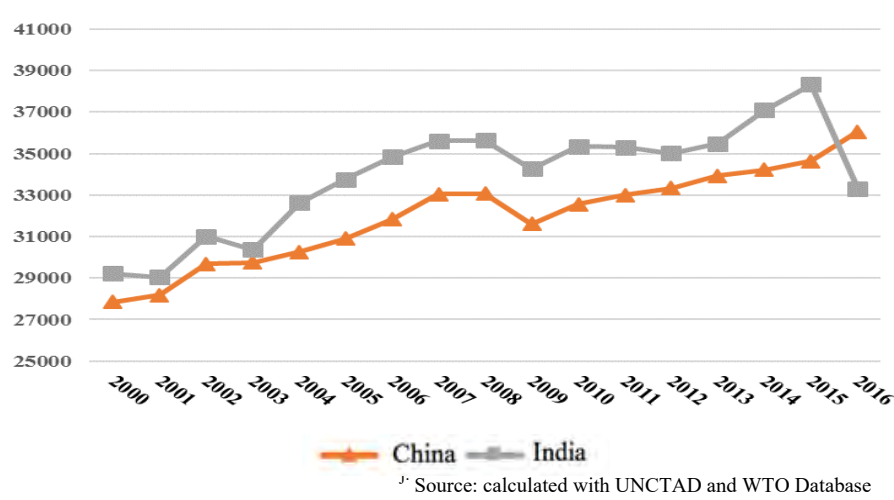

Fig. 6. Technical complexity of service export of China and India from 2000 to 2016 . 


\section{Comparative Study on the Factors Affecting the TeChNiCAl COMPLEXITY OF CHINA AND INDIA SERVICE TRADE EXPORT}

\section{A. Model and Data Sources}

Researchers studying on factors affecting the technical complexity of service export were mainly reflected in two aspects: one is using the impact factors of service trade competitiveness to indirectly examine the influencing factors of export technology complexity; on the other hand, direct analysis over factors influencing the technical complexity of service exports. Among those factors, trade openness, economic development level, foreign direct investment, human capital, trade in goods, infrastructure etc. were often used as explanatory variables [9]. Some scholars had also studied that resource endowments might play a significant role in promoting the technical complexity of service exports. Resource endowments mainly included labor, capital, and technology. The labor factors were mainly reflected in the quantity and quality of the labor force. The capital factors were reflected in the domestic investment in service sector and the inflow of foreign capital. The technology factors were reflected in the education level and R\&D investment of a country [10]. In our model we selected explanatory variables as economic development level, service trade openness, foreign direct investment, institutional quality, education level, and R\&D investment etc.

The model specification for this article is as follows:

$$
\begin{aligned}
& I n E X P Y_{t t}=\beta_{0}+\beta_{1} l n Y_{t t}+\beta_{2} O P E N_{t t}+\beta_{3} F D I_{t t}+\beta_{4} I Q_{t t} \\
& +\beta_{5} E D U_{t t}+\beta_{6} T E C H_{t t}+\mu_{t t}
\end{aligned}
$$

Wherein, the dependent variable $E X P Y_{t t}$ indicated the technical complexity of the service export of country $\mathrm{i}$ in year $\mathrm{t}$ in (3). $\beta_{\mathrm{w}}$ was the intercept term, $\ln Y_{t t}$ indicated the economic development level of a country, and Yit here was the per capita income of a country/region; $O P E N_{t t}$ indicated the degree of service trade openness of a country/region, using the ratio of import and export of service trade to GDP; $F D I_{t t}$ indicated the ratio of foreign direct investment to GDP; $I Q_{t t}$ indicated quality of governance in a country/region and was explained by the quality of government supervision in each economy [11]; $E D U_{t t}$ indicated the level of education, and was explained by enrollment rate of higher education; $T E C H_{t t}$ indicated the proportion of $R \& D$ investment to GDP; $\mu_{i \mathrm{t}}$ stood for random disturbance item.

Regarding the indicators built above, the per capita GDP, GDP, R\&D investment, and higher education enrollment data were derived from the World Bank World Development Indicator Database, and the governance quality data is derived from the World Bank's WGI. (Worldwide Governance Indicator) database, and service export data was derived from the United Nations Conference on Trade and Development (UNCTAD) and the WTO database.

\section{B. Empirical Analysis}

In order to avoid possible pseudo-regression, this paper made ADF (Augmented Dickey-Fuller) test [12]. This paper first used Eviews10.0 to test the variables in the regression models of China and India. The test results showed that the variables in China and India were first-order and single-integral, namely I(1). That is, the data of several original variables is non-stationary. After the first-order difference of the original sequence, all the data got stable and did not contain unit roots, so the sequence can be analyzed by regression.

Regression analysis of data from China and India by least squares method (OLS) [13] yielded the following results:

By observing the $\mathrm{P}$ value of China's single explanatory variable(see Table IV), it was found that the level of higher education and the level of economic development played a significant role in promoting the impact of export technical complexity. Among other explanatory variables, the impact of foreign direct investment on China was positive, and the impact of R\&D investment on China had a reverse effect. By observing the $\mathrm{P}$ value and the regression coefficients of various explanatory variables in India, it was found that the openness of service trade played a significant role in promoting the technical complexity of Indian exports. The $\mathrm{P}$ value of $\mathrm{R} \& \mathrm{D}$ investment was less than 0.1 , and it can be considered that the increase in $R \& D$ investment had a relatively weak adverse impact on Indian technical complexity.

TABLE IV. RESUlts OF MODEL REGRESSION

\begin{tabular}{|l|l|l|l|l|}
\hline & \multicolumn{1}{|c|}{$\begin{array}{c}\text { (1) } \\
\text { China }\end{array}$} & \multicolumn{1}{|c|}{$\begin{array}{c}\text { (2) } \\
\text { India }\end{array}$} & \\
\hline variables & coefficient & P value & coefficient & P value \\
\hline C & 8.298458 & 0 & 8.769664 & 0 \\
\hline EDU & $0.002887 * *$ & 0.0478 & -0.005349 & 0.4386 \\
\hline TECH & -0.182052 & 0.13 & $-0.29015^{*}$ & 0.0725 \\
\hline lnY & $0.270384 * *$ & 0.0162 & 0.238258 & 0.1871 \\
\hline IQ & 0.028525 & 0.7432 & -0.165082 & 0.2010 \\
\hline FDI & 0.015511 & 0.1313 & 0.013725 & 0.3345 \\
\hline OPEN & 0.002896 & 0.6701 & $0.019099 * *$ & 0.0314 \\
\hline $\mathrm{R}^{2}$ & 0.964663 & 45.49793 & 0.912352 & 17.34869 \\
\hline Adjusted $\mathrm{R}^{2}$ & 0.94346 & 0.000001 & 0.859762 & 0.000093 \\
\hline observations & 17 & \multicolumn{3}{|c|}{ k. note : * meant $\mathrm{p}<0.1, * *$ meant $\mathrm{p}<0.05$ 。 }
\end{tabular}

${ }^{1 .}$ Source: calculated with Eviews 10.0

In general, although China and India were both developing countries and had similarities in most aspects, the impact factors of the export technical complexity of China and India was distinct due to the different focus of the two countries in developing service trade. Nevertheless, we can find out the disadvantages in the development of China's service trade by comparing influencing factors of India's service export technical complexity with that of China's to propose relevant policies and suggestions to promote the comprehensive development of China's service trade.

\section{Empirical Analysis of Multinational Panel Data}

Baltagi (2005) [14] pointed out in the Econometric Analysis of Panel Data that, unlike the pseudo-regression of time series, when "Large N small T", the information in the 
"cross-section" would express more than the "time series". Thus, the information was stronger and did not require a stationarity check. In this paper, the number of multinational sample $\mathrm{N}$ is 34 (greater than 30), so this paper does not check the panel data for stationarity.

The Haumann test suggested to use the fixed effect model, and we found the individual fixed effect model was appropriate by $\mathrm{F}$ test. Therefore, the individual fixed effect model should be used for analysis. At the same time, in order to solve the heteroscedasticity and sequence correlation in the model, the estimation results were obtained by gradually adding explanatory variables, as shown in Table V. According to Table V, the p-value of per capita GDP was less than 0.01 , that is, it had significant at a significant level of $1 \%$. After gradually adding different variables, the regression coefficient of this variable had also been positive, which was sufficient to show that the level of economic development had a significant role in promoting the upgrading of service export technology.

Observing other explanatory variables, it could be found that the regression coefficient of the service trade openness, education level, R\&D investment were also significant at the level of $1 \%$. Among them, the regression coefficient of $R \& D$ investment was the largest. On condition each unit of service trade openness and education level being increased, the technical complexity of export would be increased by about 0.001 and 0.002 units respectively. The regression coefficients of foreign direct investment and governance quality were negative, but not significant. It cannot be said that foreign direct investment and institutional quality were counterproductive to the improvement of export technical complexity.

In summary, after empirical analysis of the factors affecting the technical complexity of service exports in 34 countries/regions, we figured out the level of economic development, service trade openness, education level and R\&D investment can improve the complexity of service export technology, among which the level of economic development could be the most important impact factors. In addition, the role of foreign direct investment and governance quality cannot be reflected in our model.

\section{CONCLUSION AND SUGGESTION}

This paper first discussed and compared the development of service trade of both China and India. Based on this, we calculated the export technical complexity, and analyzed the different performances of service export technical complexity of the two developing economies. Then we made a regression over the impact factors of export technical complexity. The results showed that: a. India's technical complexity of service export had been higher than that of China's before 2016, and the reason for this phenomenon might be a relatively loose domestic service trade development environment and advanced IT industry in India. (2) The level of economic development and the level of higher education had a significant positive impact on the technical complexity of China's service export. (3) The openness of service trade and R\&D investment had a significant positive effect on the improvement of India's service export technical complexity. The regression results of multinational panel data had also achieved the same result, but for the Chinese model, this conclusion was not valid. (4) The two factors of foreign direct investment and institutional quality had no significant effect on the technical complexity of service export in the Chinese and Indian models and in the multinational panel. Furthermore, we figured out that service trade openness and R\&D investment had not played their due role in the development of China's service trade export technical complexity. Based on this, we believed that under the current economic development level, we can improve professional labor education in service sectors, service trade openness, and R\&D investment, which will conduce to the improvement of China's service export technical complexity and the upgrading of China's service trade.

TABLE V. STIMATED RESULTS OF FIXED-EFFECT MODEL (GRADUALLY ADDING VARIABLES)

\begin{tabular}{|c|c|c|c|c|c|c|}
\hline & (1) & (2) & (3) & (4) & (5) & (6) \\
\hline \multirow[t]{2}{*}{ lny } & $\begin{array}{l}0.27830 \\
5^{* * *}\end{array}$ & $\begin{array}{l}0.2661 \\
93 * * *\end{array}$ & $\begin{array}{l}0.169347 \\
* * *\end{array}$ & $\begin{array}{l}0.169569 \\
* * *\end{array}$ & $\begin{array}{l}0.152231 \\
* * *\end{array}$ & $\begin{array}{l}0.153642 \\
* * *\end{array}$ \\
\hline & $\begin{array}{l}(0.015 \\
219)\end{array}$ & $\begin{array}{r}(0.01 \\
4961)\end{array}$ & $\begin{array}{l}\text { ( } 0.0164 \\
99)\end{array}$ & $\begin{array}{l}(0.0164 \\
74)\end{array}$ & $\begin{array}{l}(0.0172 \\
19)\end{array}$ & $\begin{array}{l}(0.0180 \\
44)\end{array}$ \\
\hline \multirow[t]{2}{*}{ open } & & $\begin{array}{l}0.0012 \\
92 * * *\end{array}$ & $\begin{array}{l}0.001031 \\
* * *\end{array}$ & $\begin{array}{l}0.001076 \\
* * *\end{array}$ & $\begin{array}{l}0.001104 \\
* * *\end{array}$ & $\begin{array}{l}0.001099 \\
* * *\end{array}$ \\
\hline & & $\begin{array}{l}(0.00 \\
0229)\end{array}$ & $\begin{array}{l}(0.0002 \\
11)^{(}\end{array}$ & $\begin{array}{l}(0.0002 \\
12)\end{array}$ & $\begin{array}{l}(0.0002 \\
11)^{(}\end{array}$ & $\begin{array}{l}(0.0002 \\
12)\end{array}$ \\
\hline \multirow[t]{2}{*}{ edu } & & & $\begin{array}{l}0.002634 \\
* * *\end{array}$ & $\begin{array}{l}0.002646 \\
* * *\end{array}$ & $\begin{array}{l}0.002382 \\
* * *\end{array}$ & $\begin{array}{l}0.002367 \\
* * *\end{array}$ \\
\hline & & & $\begin{array}{l}(0.0002 \\
52)\end{array}$ & $\begin{array}{l}(0.0002 \\
51)\end{array}$ & $\begin{array}{l}(0.0002 \\
63)\end{array}$ & $\begin{array}{l}(0.0002 \\
69)\end{array}$ \\
\hline \multirow[t]{2}{*}{ fdi } & & & & -0.000264 & -0.000207 & -0.000206 \\
\hline & & & & $\begin{array}{l}(0.0001 \\
62)\end{array}$ & $\begin{array}{l}(0.0001 \\
61)\end{array}$ & $\begin{array}{l}(0.0001 \\
62)\end{array}$ \\
\hline \multirow[t]{2}{*}{ tech } & & & & & $\begin{array}{l}0.030968 \\
* * *\end{array}$ & $\begin{array}{l}0.031009 \\
* * *\end{array}$ \\
\hline & & & & & $\begin{array}{l}\text { ( } 0.0097 \\
18)\end{array}$ & $\begin{array}{l}(0.0097 \\
27)\end{array}$ \\
\hline \multirow[t]{2}{*}{ iq } & & & & & & -0.00392 \\
\hline & & & & & & $\begin{array}{l}(0.0148 \\
45)\end{array}$ \\
\hline \multirow[t]{2}{*}{$\mathrm{c}$} & $\begin{array}{l}7.65178 \\
8^{* * *}\end{array}$ & $\begin{array}{l}7.7387 \\
4 * * *\end{array}$ & $\begin{array}{l}8.563719 \\
* * *\end{array}$ & $\begin{array}{l}8.561227 \\
* * *\end{array}$ & $\begin{array}{l}8.695936 \\
* * *\end{array}$ & $\begin{array}{l}8.68687^{*} \\
* *\end{array}$ \\
\hline & $\begin{array}{l}(0.152 \\
929)\end{array}$ & $\begin{array}{c}(0.14 \\
9581)\end{array}$ & $\begin{array}{l}(0.1576 \\
78)\end{array}$ & $\begin{array}{l}(0.1574 \\
44)\end{array}$ & $\begin{array}{l}(0.1617 \\
47)\end{array}$ & $\begin{array}{l}(0.1654 \\
87)\end{array}$ \\
\hline $\mathrm{R}^{2}$ & $\begin{array}{l}0.80523 \\
2 \\
\end{array}$ & $\begin{array}{l}0.8159 \\
93 \\
\end{array}$ & 0.846955 & 0.847706 & 0.850522 & 0.850542 \\
\hline \multicolumn{2}{|c|}{ Observations } & 578 & & & & \\
\hline
\end{tabular}

\section{ACKNOWLEDGMENT}

This research was sponsored by the Central University Fundamental Science and Research findings of Beijing Forestry University (Project No.: 2017ZY58; 2017ZY57), and National Social Science Foundation of China (Project No.: 17BJY018).

\section{REFERENCE}

[1] Y.X. Wang, "Research on the countermeasures for improving the competitiveness of China's service trade," University of International Business and Economics, vol. 2017 (5), pp. 16, 2017.

[2] X.R. Lu, "Comparative Study on Knowledge-intensive Service Trade between China and India," Jiangsu Science and Technology Information, vol. 7(21), pp. 42-48, 2017.

[3] D. Burgess, "Services as Intermediate Goods: the Issue of Trade Liberalization," In Jones R and Kruger A (eds), The Political Economy of International Trade, Blackwell, 1990, pp. 122-139. 
[4] R.X. Lu, Research on the interaction between service trade and goods trade, Beijing: China Economic Publishing House, vol. 11, pp. 15-17, 2015.

[5] Y.S. Du, "Empirical Study on the Impact of Export Technology Complexity on China's Economic Growth: Based on Different Trade Modes and Enterprise Nature," International Trade Issues, vol. 2014(9), pp. 3-12, 2014.

[6] W.H and H.J. L, "The Impact of Technology Trade Export Technology Complexity Upgrade on Economic Growth: An Empirical Analysis Based on Multinational Panel Data," Trade Research, vol. 2016(5), pp. 89, 2016.

[7] W. Lu and W. Zhang, "Analysis of the Structure of India's Service Trade," Guangdong Social Sciences, vol. 2015(5), pp. 55-63, 2015.

[8] X.H. Chen and C.Y. Shen, "Review and review of the research on the complexity of export technology," Journal of Zhejiang Sci-Tech University, vol. 2015(5), pp. 371-372, 2015.

[9] Y.L. Zou and X.B. Xing, "Research on the Technology Complexity of Service Trade Export and Its Influencing Factors: Based on Comparative
Analysis of Panel Data in OECD Countries," Journal of Chongqing University of Science and Technology, vol. 2017(12), pp. 47, 2017.

[10] K.P. Yang, "Research on the complexity of China's service export technology and its influencing factors: New understanding based on value-added trade perspective," Anhui University of Finance and Economics, vol. 2016(12), pp. 66-68, 2016.

[11] Z.M. Yin and J. Gong, "Research on Technology Complexity and Influencing Factors of Service Trade Export: Empirical Analysis Based on Panel Data of 80 Countries (Regions)," Journal of Yunnan University of Finance and Economics, vol. 2014(5), pp. 66-74, 2014.

[12] D.A. Dickey and W.A. Fuller, "Likelihood Ratio Statistics for Autoregressive Time Series with a Unit Root," The Econometric Society, pp. 1057-1072, 1981.

[13] C.Q. Li and J. Lu, "R\&D, financing constraints and export greensophistication in China," China Economics Review, pp. 234-244, 2018.

[14] B.H. Baltagi, "Econometric Analysis of Panel Data," John Wiley \& Sons Ltd, pp. 196-197, 2015. 